\title{
Impact of Nitrogen and Boron on Some Vegetative, Reproductive and Quality of Guava (Psidium gujava L.)
}

\author{
Bibha Kumari*, Suraj Prakash, U.S. Jaiswal and Radheyshyam \\ Department of Horticulture (Fruit \& Fruit Tech.) Bihar Agricultural University, Sabour, \\ Bhagalpur-813210, India \\ *Corresponding author
}

\section{A B S T R A C T}

Keywords

Nitrogen, Boron, level, yield and quality

Article Info

Accepted:

12 March 2018

Available Online:

10 April 2018
The experiment was under taken to study the effect of nitrogen and boron on growth, yield and quality of winter guava fruit. The vegetative parameters increased with increasing doses of nitrogen and maximum percent increase in plant height $(17.08 \%)$, shoot length $(64.71 \mathrm{~cm})$, tree girth $(7.24 \%)$ and plant spread $(15.15 \%)$ were obtained with application of nitrogen@800 g/plant. The fruit yield $(52.89 \mathrm{~kg} / \mathrm{plant})$ and fruit yield efficiency $(5.87 \mathrm{~kg} / \mathrm{plant})$ were obtained with nitrogen @ $600 \mathrm{~g} / \mathrm{plant}$, Whileboron applied @ $50 \mathrm{~g} /$ plant produced maximum fruit yield (57.09 $\mathrm{kg} / \mathrm{plant})$ and fruit yield efficiency $(6.13 \mathrm{~kg} / \mathrm{plant})$. The maximum TSS $\left(13.43^{0} \mathrm{~B}\right)$, ascorbic acid $(259.32 \mathrm{mg} / 100 \mathrm{~g}$ of pulp) and total sugar $(7.17 \%)$ were found with application of boron @ $50 \mathrm{~g} / \mathrm{plant}$.

\section{Introduction}

Guava (Psidium guajava L) belongs to family myrtaceae and native to tropical America. It is being grown commercially in the tropical as well as subtropical parts of all over the world. As an important crop of India, it has gain considerable prominence on account of its high nutritive value, availability of moderate price, a pleasant aroma and good flavour, so that it's called as 'apple of tropics'. In Northern India, guava flowers twice in a year, first in March-April for rainy season crop and second in July-August for winter season crop. This cropping behaviour of guava enables the growers to take either rainy season crop or winter season crop in a year. However, Bihar, especially in the alluvial soils of IndoGangetic plains, the maximum yield is produced during rainy season crop (Singh, 2000). The natural fruit setting in guava is quite high (80-86 \%) of which only 34-36 per cent fruits reach maturity (Mitra and Bose, 1990). The fruit drop in guava may occur due to various physiological and environmental factors (Mitra and Bose, 1990). Kundu et al., (2007) working with Sardar guava in West Bengal, classified the fruit growth into 3 distinct stages, viz; Stage I, in which fruit growth was rapid for first 50 days of fruit 
setting; Stage II, in between 50 and 90 days of fruit setting, when growth was very slow; and Stage III, in which an exponential increase in rate of fruit growth was noted between 90-120 days. The weight and size of fruits gradually increased at the first phase, then slowed down and finally increased till maturity. The duration of all 3 growth phases appeared to be inversely proportional to prevailing temperatures (Mitra and Bose, 1990). The days from anthesis to harvesting can vary from 120 to 220 days depending upon temperature during fruit development. The fruit harvested in rainy seasons are small in size, inferior in quality, insipid and highly perishable (Hedge and Chharia, 2004). But, the fruits harvested in wither season are larger in size, superior in quality, sweet and shining fruits. Nutrients are essential for the productivity and quality of guava fruits. Hence, determination of nutritional needs for efficient production of high quality fruits is important aspect of nutrient management for the orchardists.

Nitrogen plays a dominant role because it is an essential constituent of protein, nucleic acid, nucleotide, amino acids, protoplasm, chlorophyll, Intro Phospholipids, alkaloid, enzymes, harmones, vitamins, etc. It is a part of purines, pyrimidine, prophyrines and coenzymes. It is essential for carbohydrates utilization within plants. It imparts vigorous vegetative growth and dark green colour to plants, produces early growth and delays maturity of plants, and governs the utilization of potassium, phosphorus and other elements.

Boron is the key nutrient for flowering, fruiting and as well as the internal and external fruit quality. It is involved in sugar transport, lignifications, RNA metabolism, respiration, indole acetic acid (IAA) metabolism, cell wall synthesis, carbohydrate metabolism etc. (Jeremy, 2007). In fruit crops, Boron deficient trees exhibit little shoot growth, some buds may fail to open, whereas others may open and then shrivel and die. Shoots may grow for some time and then tips cease growth and die. Leaves are distorted in shape, with regular serration; leaves may cup or roll in a downward direction and feel thick and leathery. Fruits may become hard shriveled and blotchy. The experiment was formulated to assess the sources of nitrogen and their level of growth, yield and quality of guava.

\section{Materials and Methods}

The investigations were carried out at Bihar Agricultural College, Sabour, and Bhagalpur during the winter season of the year 2012 and 2013. The experiment was conducted on nine years old plants of guava cv. "Allahabad Safeda' during winter season. Sabour is situated under subtropical zone between $25^{\circ}$ $15^{\prime} 40^{\prime \prime}$ north altitudes and $87^{\circ} 12^{\prime} 42^{\prime \prime}$ east longitudes, at an altitude of 45.72 meters above mean sea level. It has a semi-arid, subtropical climate with hot desiccating summer, cold but frostless winter with an average rainfall about $1040 \mathrm{~mm}$. The soil of orchard is loam, deep and well drained. Nitrogen were used from urea and calcium ammonium nitrate (CAN) and levels of nitrogen applied (a.i) @ 400, 600 \& 800 g/plant. Phosphorous and potassium applied uniformly in all the treatments. The $2 / 3^{\text {rd }}$ and $1 / 3^{\text {rd }}$ dose of nitrogen applied during last week of June and September respectively. The experiment was laid out in Randomized Block Design (Factorial) replicated thrice. Tree girth was recorded in centimetre by measuring circumference at $30 \mathrm{~cm}$ above the ground with the help of a meter tape at beginning of the experiment and at the end of the fruiting The height of tree was measured in meter from the ground surface to top of the tree vertically with the help of a scaled bamboo pole (marked in meter) both at the initiation of the experiment and at the end of the fruiting. New vegetative shoots on individual branch, in all 
the four directions, i.e. East West and NorthSouth were tagged and measured with the help of measuring tape and average value expressed in $\mathrm{cm}$. Two bamboo poles were kept vertically straight touching the sides of the canopy of each tree on east and west and the distance between the two poles was measured in meters with the help of a measuring tape. The canopy spread was also measured in north-south direction in the same way and then average of N-S and E-W spread was calculated. Canopy volume was calculated by following formula of a oblate spheroid canopy as suggested by Westwood (1978).

Tree volume $=4 / 3^{\wedge} \mathrm{a} 2 \mathrm{~b}=4.189 \mathrm{a} 2 \mathrm{~b}$

Where, $a=1 / 2 \times$ canopy spread; $b=1 / 2 \times$ canopy height.

The yield of fruits per plant was recorded by weighing the harvested fruits in different pickings. Fruits yield efficiency was recorded by weighing fruits in a square meter in different pickings. The total soluble solids of the fruit juice was estimated with the help of a hand refractometer and expressed as $\left({ }^{0} \mathrm{~B}\right)$. Ascorbic acid in guava determined by titrated against 2,6-dichlorophenol indophenol dye solution to a faint pink end point which persisted for 15 seconds (A.O.A.C., 1984). The vitamin $\mathrm{C}$ content of fruit was expressed as milligrams of ascorbic acid per $100 \mathrm{~g}$ of pulp. Total sugars were determined by the method of Lane and Eyon (1923). Aliquots of filtrate were titrated against $0.1 \mathrm{~N}$ Sodium hydroxide solution using phenolphthalein as indicator and the titratable acidity was expressed as percentage of anhydrous citric acid per $100 \mathrm{~g}$ of the pulp.

\section{Results and Discussion}

Soil application of Nitrogen to guava plant showed beneficial effect on vegetative growth parameters. Perusal of data presented in Table
1 indicated that plant height, length of shoots, plant girth and plant spread increased with increasing levels of nitrogen. Significantly maximum plant height (17.08\%), shoot length $(64.71 \mathrm{~cm})$, tree girth $(7.24 \%)$ and plant spread $(15.15 \%)$ were recorded with application of $800 \mathrm{~g}$ nitrogen /plant. Minimum plant height, shoot length, tree girth and plant spread were recorded under nitrogen applied @ $400 \mathrm{~g} / \mathrm{plant}$. It was observed that increasing levels of nitrogen increased the vegetative parameters in progressive manner. The effect of doses of boron was not shown pronounced effect on vegetative growth parameters.

The maximum increase in tree girth i.e., 7.10 $\%$ was obtained with boron applied @ 50 g/plant, which was statically at par with $7.05 \%$ when boron applied @75 g/plant. Regarding vegetative growth, nitrogen supplied through urea performed better than calcium ammonium nitrate. The effect of boron did not show significant variation on vegetative parameters. It could be attributed to increase in nutrient availability and thus leads to vigorous plant growth. The possible reason for increase in these parameters by soil application reported by Pathak and Ram 2005; Aseri et al., 2006 and Goswamie et al., 2012).

Perusal of data from Table 2 and 3 showed that Nitrogen has significant effect on fruit set per cent, days of harvesting, fruit drop per cent, fruit yield efficiency, fruit weight and pulp weight. Significantly higher fruit yield efficiency $(5.87 \mathrm{~kg} /$ plant $)$ and fruit set $(70.46$ $\%)$, fruit weight (296.67 $\mathrm{g}$ ) and pulp weight $(269.48 \mathrm{~g})$ were obtained when nitrogen applied @600 g/plant. Whereas, least number of days for harvesting i.e., 102.61 days and minimum fruit drop $(37.43 \%)$ were noticed when nitrogen applied @ $800 \mathrm{~g} /$ plant, which is statistically similar with application of nitrogen@600 g/plant. The number of days for harvesting reduced by one week. 
Table.1 Effect of nitrogen and boron on vegetative parameters of guava plant. (Pooled data two year)

\begin{tabular}{|c|c|c|c|c|}
\hline Treatment & $\begin{array}{l}\% \text { increase in } \\
\text { plant height }\end{array}$ & Length of shoots (cm) & $\%$ increase in plant girth & $\begin{array}{c}\% \text { increases in plant } \\
\text { spread }\end{array}$ \\
\hline \multicolumn{5}{|l|}{ Effect of nitrogen } \\
\hline Nitrogen@400 g/plant & 9.01 & 42.74 & 6.75 & 8.78 \\
\hline Nitrogen@600 g/plant & 14.70 & 53.95 & 6.97 & 12.72 \\
\hline Nitrogen@800 g/plant & 17.08 & 64.71 & 7.24 & 15.15 \\
\hline $\mathrm{SE} \pm \mathrm{m}$ & 0.07 & 0.36 & 0.04 & 0.09 \\
\hline C D at $5 \%$ & 0.22 & 1.04 & 0.13 & 0.25 \\
\hline \multicolumn{5}{|l|}{ Effect of boron } \\
\hline Boron@0 g/plant & 13.46 & 52.74 & 6.80 & 11.56 \\
\hline Boron@50 g/plant & 13.59 & 53.68 & 7.10 & 12.56 \\
\hline Boron@ 95 g/plant & 13.74 & 54.98 & 7.05 & 12.57 \\
\hline $\mathrm{SE} \pm$ mean & ----- & 0.36 & 0.04 & 0.08 \\
\hline CD@5\% & N S & 1.04 & 0.13 & 0.24 \\
\hline
\end{tabular}

Table.2 Effect of nitrogen and boron on yield contributing parameters of guava plant. (Pooled data two year)

\begin{tabular}{|c|c|c|c|c|}
\hline Treatment & Fruit set (\%) & Days of harvest /maturity & Fruit drop (\%) & $\begin{array}{l}\text { Fruit Yield efficiency } \\
\text { (Kg/plant) }\end{array}$ \\
\hline \multicolumn{5}{|l|}{ Effect of nitrogen } \\
\hline Nitrogen @ 400 g/plant & $66.52(54.73)$ & 108.92 & 41.22 & 4.79 \\
\hline Nitrogen@600 g/plant & $70.46(57.20)$ & 103.14 & 39.21 & 5.87 \\
\hline Nitrogen@800 g/plant & $69.77(56.79)$ & 102.61 & 37.43 & 5.30 \\
\hline $\mathrm{SE} \pm \mathrm{m}$ & 0.25 & 2.01 & 0.18 & 0.38 \\
\hline C D at $5 \%$ & 0.70 & 0.71 & 0.52 & 0.10 \\
\hline \multicolumn{5}{|l|}{ Effect of boron } \\
\hline Boron@0 g/plant & $61.28(51.54)$ & 115.86 & 44.60 & 4.93 \\
\hline Boron@50 g/plant & $74.67(59.83)$ & 98.86 & 36.96 & 6.13 \\
\hline Boron@ 75 g/plant & $70.83(57.35)$ & 99.95 & 36.31 & 5.86 \\
\hline $\mathrm{SE} \pm$ mean & 0.25 & 2.01 & 0.18 & 0.38 \\
\hline CD@5\% & 0.72 & 0.71 & 0.52 & 0.10 \\
\hline
\end{tabular}


Table.3 Effect of nitrogen and boron on yield contributing parameters of guava plant. (Pooled data two year)

\begin{tabular}{|c|c|c|}
\hline Treatment & Fruit weight (g) & Pulp weight (g) \\
\hline \multicolumn{3}{|l|}{ Effect of nitrogen } \\
\hline Nitrogen@400 g/plant & 247.07 & 223.99 \\
\hline Nitrogen@600 g/plant & 296.67 & 269.48 \\
\hline Nitrogen@800 g/plant & 290.31 & 265.48 \\
\hline $\mathrm{SE} \pm \mathrm{m}$ & 1.95 & 2.09 \\
\hline C D at $5 \%$ & 5.49 & 5.91 \\
\hline \multicolumn{3}{|l|}{ Effect of boron } \\
\hline Boron@0g/plant & 224.49 & 201.21 \\
\hline Boron@50 g/plant & 317.30 & 285.97 \\
\hline Boron@75 g/plant & 302.27 & 276.77 \\
\hline $\mathrm{SE} \pm$ mean & 1.49 & 2.09 \\
\hline CD@5\% & 1.95 & 5.91 \\
\hline
\end{tabular}

Table.4 Effect of nitrogen and boron on quality contributing parameters of guava plant. (Pooled data two year)

\begin{tabular}{|c|c|c|c|c|}
\hline Treatment & $\operatorname{TSS}\left({ }^{0} \mathrm{~B}\right)$ & Ascorbic acid (mg/100 $\mathrm{g}$ of pulp) & Total Sugar (\%) & Acidity (\%) \\
\hline \multicolumn{5}{|l|}{ Effect of nitrogen } \\
\hline Nitrogen@400 g/plant & 10.07 & 233.76 & 6.00 & 0.317 \\
\hline Nitrogen@600 g/plant & 11.55 & 260.79 & 7.58 & 0.342 \\
\hline Nitrogen@800g/plant & 11.17 & 261.64 & 7.21 & 0.374 \\
\hline $\mathrm{SE} \pm \mathrm{m}$ & 0.06 & 1.15 & 0.03 & 0.001 \\
\hline C D at $5 \%$ & 0.19 & 3.24 & 0.09 & 0.005 \\
\hline \multicolumn{5}{|l|}{ Effect of boron } \\
\hline Boron@0 g/plant & 10.22 & 235.30 & 6.48 & 0.319 \\
\hline Boron@50 g/plant & 13.43 & 259.32 & 7.17 & 0.357 \\
\hline Boron@ 75 g/plant & 11.14 & 261.57 & 7.15 & 0.357 \\
\hline $\mathrm{SE} \pm$ mean & 0.08 & 1.16 & 0.03 & 0.001 \\
\hline CD@5\% & 0.25 & 3.29 & 0.09 & 0.005 \\
\hline
\end{tabular}


Graph.1 Effect of Nitrogen and Boron on yield/ plant of guava (pooled data two year)

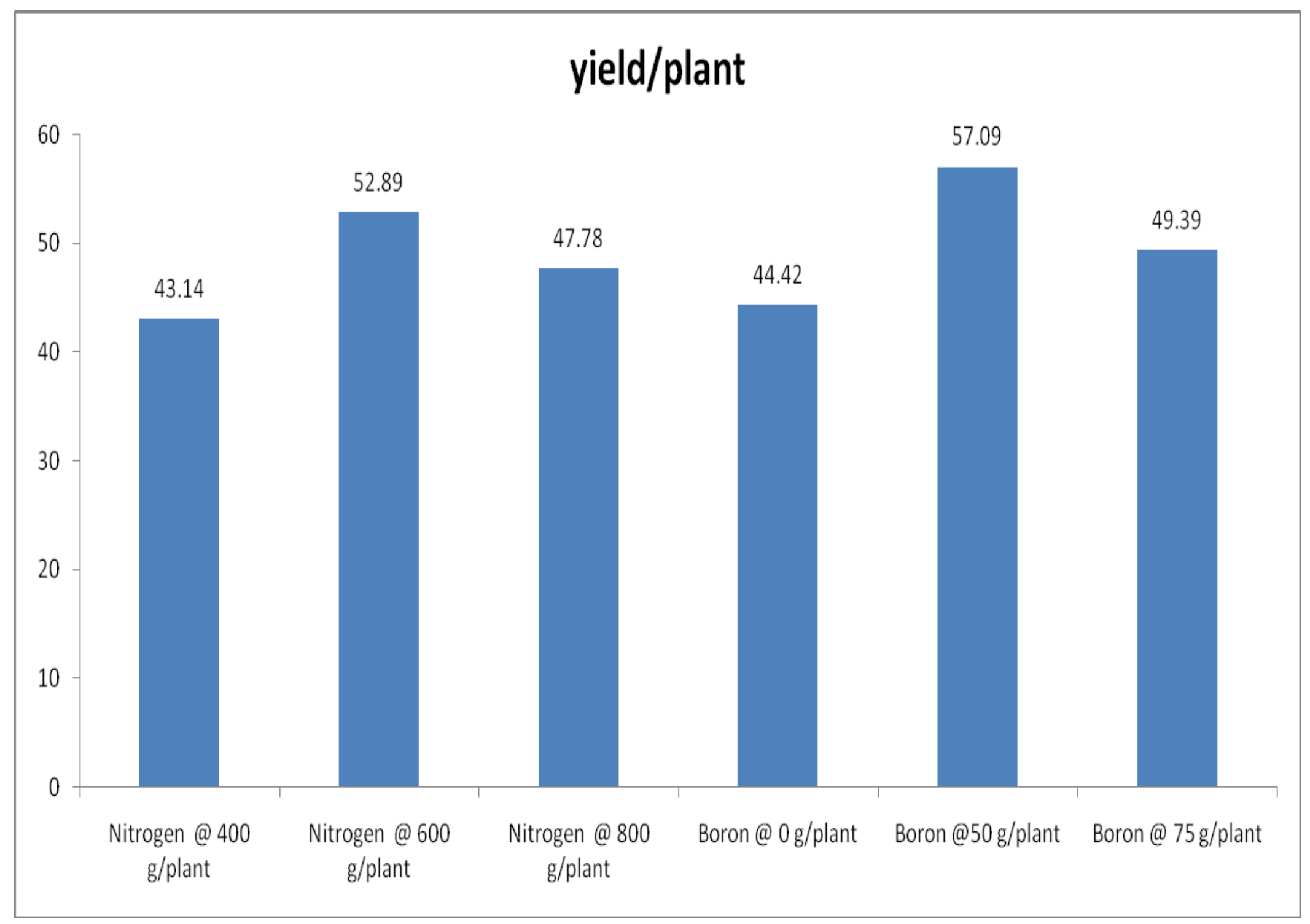


Fruit yield efficiency enhanced from 4.79 $\mathrm{kg} / \mathrm{m}^{2}$ to $5.87 \mathrm{~kg} / \mathrm{m}^{2}$ Soil application of Nitrogen leads to early flowering might be due to synthesis of nucleic acid, which in turn influenced the formation of flower bud primordial, advanced the completion of physiological process involved in blossoming. The results of present finding are in supports with Goswami et al., 2012 and Sharma et al., 2013).

The main effect of boron showed an increasing trend of fruit set. Maximum fruit set was obtained i.e., $74.67 \%$ when boron applied@50 g/plant. Whereas increase in boron quantity revealed declining fruit set per cent. When boron applied @ 50g/plant harvested the fruit 17 days prior in comparison to without application of boron. Whereas, doses of boron does not create much variation in advancement of harvesting period. The minimum fruit drop was recorded i.e., $36.31 \%$ when boron applied @ 75g/plant, which was statically at par with $36.96 \%$ when boron applied @ $50 \mathrm{~g} / \mathrm{plant}$. Impacts of boron on yield contributing characters have a positive effect. The fruit yield efficiency enhanced from $4.93 \mathrm{~kg} / \mathrm{m} 2$ to $6.13 \mathrm{~kg} / \mathrm{m} 2$. An increase in yield of $1.2 \mathrm{~kg} / \mathrm{m} 2$ has been observed with application of boron @ 50 $\mathrm{g} /$ plant. The maximum fruit weight $(317.30 \mathrm{~g})$ and pulp weight $(285.97 \mathrm{~g})$ were observed with soil application of boron @ $50 \mathrm{~g}$ /plant. Whereas, an increase in dose of boron @ 75 g/plant did not show significant positive corelation with yield as well size of fruit. The fruit becomes round in shape rather than elongated although it is genetic character. But it seems that soil application of boron has influence on diameter than length. Soil application of boron leads to early flowering might be due to synthesis of nucleic acid, which in turn influenced the formation of flower bud primordial, advanced the completion of physiological process involved in blossoming. Boron plays an important role in pollen tube formation, fertilization their by increasing fruit set percentage and decreasing fruit drop per cent. The time required from flowering to harvesting deceased by 17 days with application of B 50g/plant. The lowest fruit drop due to borax treatments might be due to involvement of boron on carbohydrate which might be helpful in checking fruit drop. It also assists in auxin balance to prevent fruit drop. The increase in content of auxin may be attributed to different factors like increased synthesis of tryptophan which is precursor of auxin presumably resulting from an increased activity or synthesis of tryptophan synthatase or to the inactivation of peroxidase activity, leading to more accumulation of auxin. The results of present finding are in supports with Goswami et al., 2012 and Sharma et al., 2013.

The yield of plant is directly related to nutrient status of soil, amount of nutrient applied, amount of nutrient observed by plant. The significantly higher yield $(57.09 \mathrm{~kg} / \mathrm{plant})$ and $(52.89 \mathrm{~kg} / \mathrm{plant})$ were observed with application of boron @ 50 g/plant and nitrogen@600 g/plant respectively from (Graph-1). An increase in yield $12.67 \mathrm{~kg} / \mathrm{plant}$ may be noticed on without application boron. Doses of nitrogen enhanced from $400 \mathrm{~g} / \mathrm{plant}$ to $600 \mathrm{~g} / \mathrm{plant}$, an increase in yield of 9.75 $\mathrm{kg} /$ plant was obtained. Further increase in doses on nitrogen did not show positive impact on yield.

The data pertaining to fruit quality characters as influenced by nitrogen and boron have been presented in Table 4 . The TSS, ascorbic acid, acidity and total sugar increased with increasing levels of nitrogen from $400 \mathrm{~g}$ to $800 \mathrm{~g} /$ tree being the maximum with the application of $600 \mathrm{~g}$ nitrogen/tree. Significantly maximum TSS $\left(11.55^{0} \quad \mathrm{~B}\right)$, ascorbic acid (260.79 mg/100 g of pulp) and total sugar $(7.58 \%)$ were found with nitrogen @ $600 \mathrm{~g} / \mathrm{plant}$. Whereas, maximum acidity $(0.37 \%)$ was recorded with nitrogen @ 800 
g/plant. However, minimum TSS, ascorbic acid and total sugar was observed when nitrogen applied @ 400 g/plant.

Perusal of data on fruit quality characters as influenced by boron have been presented in Table 4. The TSS, ascorbic acid, total sugar and acidity increased with boron from $0 \mathrm{~g}$ to $75 \mathrm{~g} /$ plant being the maximum with the application of $50 \mathrm{~g}$ boron/plant. Significantly maximum TSS (13.43* B), ascorbic acid (259.32mg/100 g of pulp) total sugar $(7.17 \%)$ and acidity $(0.36 \%)$ were found with boron (a) $50 \mathrm{~g} / \mathrm{plant}$. However, minimum TSS, ascorbic acid, total sugar and acidity was observed without boron. The findings are in conformity with Hundal et al., (2007), Hari et al., (2008) and Kumar et al., (2009).

Application of Urea @ 800 g/plant had more pronounced effect on vegetative growth rather than reproductive parameters. From above depicted table and graph, it is found that the nitrogen@600 g/plant and boron@ @ 50 g /plant are the best for improving yield contributing character as well as yield and quality attributes of guava fruits.

\section{References}

A.O.A.C (1984) Official method of analysis $\left(14^{\text {th }}\right.$ Ed.) Association of Official Agricultural Chemistry, Washington, D. C., pp.16.

Aseri GK, Jain N, Panwar J, Rao AV, Meghwal PR (2006) Biofertlilzers improves plant growth, fruit yield, nutrition metabolism and rhizosphere enzyme activates of pomegranate (Punica granatum L) in Indian Thar desert. Scientia Hort. 117:130-135.

Aseri GK, Jain N, Panwar J, Rao AV, Meghwal PR (2008) Biofertlilzers improves plant growth, fruit yield, nutrition metabolism and rhizosphere enzyme activates of pomegranate
(Punica granatum L) in Indian Thar desert. Scientia Hort. 117:130-135.

Athani SI, Revanappa, Allollt TB (2009) Influence of organic and inorganic fertilizers on growth, fruit characters, nutrient content and yield in guava. J. of Ecobiol.26: 131-138.

Dinesh Kumar, Pandey V, Anjaneyulu K, Vishal Nath (2009).Optimization of major nutrients of guava yield and quality under east coastal conditions. Indian J. of Hort. 66 (1): 18-21.

Goswami HS, Shukla, Prabhat Kumar, Misra DS (2012) Effect of pre-harvest application of micro-nutrients on quality of guava (Psidium guajava L) cv. Sardar.Hort. Flora Res. Spectrum. 1: (1): 60-63.

Hari B, Rajesh Y, Dwivedi R (2008). Effect of INM on growth, yield, yield attributing characters and quality of guava (Psidium guajava L.) cv. Sardar.

Hundal HS, Dhanwinder Singh, Kuldip Singh (2007). Monitoring nutrient status of guava fruit trees in Punjab. North West India through the diagnostic and recommendation integrated system approach. Communication in Soil Sci. and Plant Anal. 38 (15/16): 2117-2130.

Jeremy, O' Brien (2007) Boron and calcium together in plant nutrition. Albion Metalosate plant nutrition Newsletter 8: 2.

Kumar O, Pandey V, Anganeyulu K, Vishal Nath (2009) Optimization of major nutrients for guava yield and quality under east coastal conditions. Indian J. Hort. 66; (1): 18-21.

Kundu S, Ghosh B, Mitra SK, Mazumdar D (2007) Effect of foliar spraying of nitrogen, phosphorous and potassium on yield and fruit quality of guava (Psidium gujava L). Acta Hort. 735; 433-440.

Lane JH, Eyon I (1923) Determination of sugar by Fehling's solution with 
methylene as indicator. J. Soc. Chem. Ind., 42: 32

Mitra SK, Bose TK (1990). Guava in Fruits: Tropical and Sub-tropical (Edn) Naya Prakash, Kolkata: 280-303.

Pathak R K, Ram R A (2005) Integration of organic farming practices for sustainable production of guava. In: First International guava Symposium, 4-5 Dec, 2005, CISH Lucknow, India P $144-45$.

Sharma VK, Wali RM, Mahital Jamwal, Bindya Sharma (2013) Effectiveness of various crop regulation treatments in Guava (Psidium gujava L) cv. L-49. Madaras Agric. J. (1-3): 92-94.

Singh HK, Srivastava AK, Dwivedi R, Kumar $P$ (2001). Effect of foliar feeding of micronutrients on plant growth, fruit quality, yield and internal fruit necrosis of aonla (Emblica officinalis Gaertn.) cv. Francis. Prog. Hort., 33 (1): 80-83.

Singh NP, Rajput CBS (1977).Chemical composition of guava (Psidium guajava L.) fruit as influenced by nitrogen application. Prog. Hort., 9 (2): 67-70.

\section{How to cite this article:}

Bibha Kumari, Suraj Prakash, U.S. Jaiswal and Radheyshyam. 2018. Impact of Nitrogen and Boron on Some Vegetative, Reproductive and Quality of Guava (Psidium gujava L.). Int.J.Curr.Microbiol.App.Sci. 7(04): 1752-1760. doi: https://doi.org/10.20546/ijcmas.2018.704.199 